\title{
Title:
}

\section{Large bowel obstruction secondary to simple renal cyst: an exceptional complication}

\section{Authors:}

Margarita Fernández-de la Varga, Isabel Pérez Valle, Carlos Ordieres Díaz, Pedro Amor Martín, Marta Álvarez Posadilla, Adrián Huergo Fernández

DOI: $10.17235 /$ reed.2022.8623/2022

Link: PubMed (Epub ahead of print)

Please cite this article as:

Fernández-de la Varga Margarita, Pérez Valle Isabel, Ordieres Díaz Carlos, Amor Martín Pedro, Álvarez Posadilla Marta, Huergo Fernández Adrián. Large bowel obstruction secondary to simple renal cyst: an exceptional complication. Rev Esp Enferm Dig 2022. doi: 10.17235/reed.2022.8623/2022.

This is a PDF file of an unedited manuscript that has been accepted for publication. As a service to our customers we are providing this early version of the manuscript. The manuscript will undergo copyediting, typesetting, and review of the resulting proof before it is published in its final form. Please note that during the production process errors may be discovered which could affect the content, and all legal disclaimers that apply to the journal pertain. 


\section{Large bowel obstruction secondary to simple renal cyst: an exceptional complication}

Margarita Fernández-de la Varga, Isabel Pérez-Valle, Carlos Ordieres Díaz, Pedro Amor Martín, Marta Álvarez-Posadilla, Adrián Huergo Fernández

Clinical Management Unit of Digestive Diseases, Hospital Universitario Álvarez Buylla

\section{Corresponding author:}

Margarita Fernández-de la Varga.

Address: Hospital Universitario Álvarez Buylla, UGC Aparato Digestivo (Despacho planta 1). Calle Vistalegre 2, 33611 Mieres (Asturias)

Email: margafvarga@gmail.com

Dear Editor,

Simple renal cysts are a benign entity very commonly encountered in abdominal imaging; their prevalence is higher than $50 \%$ in patients aged 50 years and older. The vast majority of patients do not present symptoms, even if the cysts are big, although this increase in size can produce symptoms in exceptional cases (compression, infection, bleeding...).

We present the case of a patient with large bowel obstruction conditioned by a big simple renal cyst.

\section{CASE REPORT}

We report the case of an 81-year-old female who presents to the Emergency room with abdominal pain and tenderness that have been present for almost 15 days, with no bowel movements during the last 72 hours. Physical examination revealed diffuse abdominal pain; abdomen was distended and tympanic to percussion, with diminished bowel sounds, but no peritoneal signs were found. 
Blood test presented elevation of acute phase reactants, with $16000 / \mathrm{mm}^{3}$ leukocytes and C-Reactive Protein level of $9.2 \mathrm{mg} / \mathrm{dL}$ (upper limit of normal is $0.5 \mathrm{mg} / \mathrm{dL}$ ). Abdominal radiography revealed the presence of large bowel distention and absence of rectal gas, suggestive of large-bowel obstruction. Abdominal CT scan showed voluminous bilateral simple renal cysts; the biggest one $(16 \mathrm{~cm})$, located at left kidney, was producing a compression of the descending colon against the abdominal wall (Figures $1 \mathrm{~A}$ and $1 \mathrm{~B}$ ).

Percutaneous drainage of the renal cyst was performed by a urologist. The follow-up CT scan revealed a collapsed cyst with resolution of the bowel obstruction (Figure 1C). The patient showed resolution of the symptoms with an improvement in blood test results.

\section{DISCUSSION}

Large bowel obstruction is a surgical emergency in which a mechanical cause produces a partial or total interruption of the intestinal transit(1). It is important to identify the cause of the obstruction, as it will determine the election of the treatment(2).

Of note, even though simple renal cysts are very common lesions in elderly people, the vast majority of them are asymptomatic, requiring a treatment only in giant cysts causing symptoms(3), being the large bowel obstruction a very rare presentation(4).

\section{REFERENCES}

1. Farkas NG, Welman TJP, Ross T et al. Unusual causes of large bowel obstruction. Curr Probl Surg. 2019;56(2):49-90

2. Johnson WR, Hawkins AT. Large Bowel Obstruction. Clin Colon Rectal Surg. 2021;34(4):233-41

3. Bas O, Nalbant I, Can Sener $\mathrm{N}$ et al. Management of renal cysts. JSLS. 
2015;19(1):1-6

4. Sadeghi A, Shahrbaf MA, Asadzadeh Aghdaei $\mathrm{H}$ et al. A rare presentation of simple renal cyst: gastrointestinal obstruction. Gastroenterol Hepatol Bed Bench. 2018;11(4):359-362.

\section{CONFLICT OF INTEREST}

The authors have no conflicts of interest to disclose. 


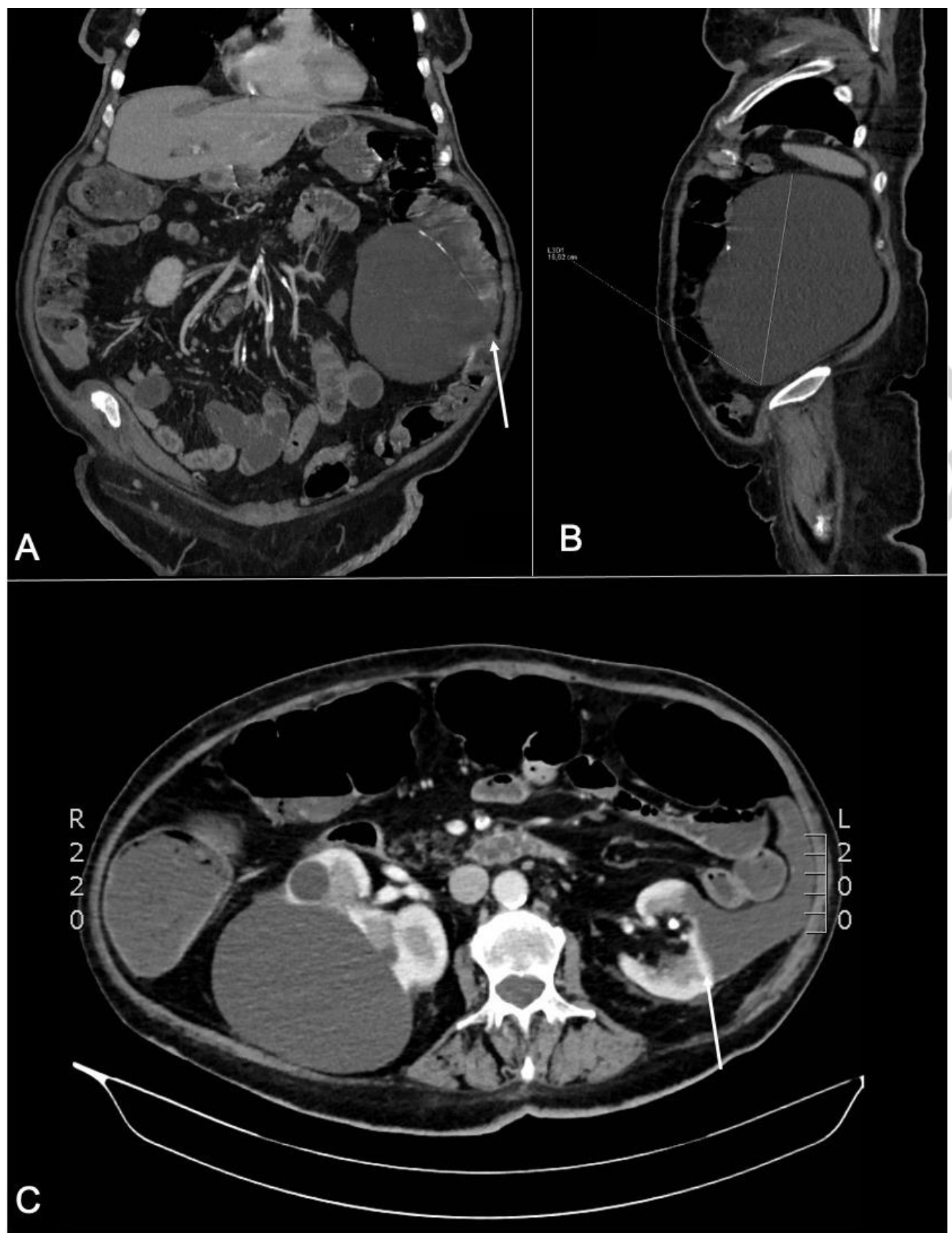

Figure 1: Abdominal CT scan: coronal plane (1A) and sagittal plane (1B), showing a left renal cyst measuring $16 \mathrm{~cm}$, producing a compression of the left colon against the abdominal wall (arrow). Figure 1C: follow-up CT scan (axial plane) after drainage, showing the left renal cyst almost completely collapsed with partial occupation of the left paracolic gutter (arrow) and resolution of the bowel obstruction. 